\title{
AN EXPERIMENTAL STUDY: IMPROVING STUDENTS' VOCABULARY MASTERY BY USING ENGLISH SONGS
}

\author{
Rizky Gushendra \\ State Islamic University of Sultan Syarif Kasim Riau, Indonesia \\ ricky82pku@gmail.com
}

\begin{abstract}
Based on the writer's observation in teaching and learning process, the students had low achievement in vocabulary mastery in learning English. Memorizing vocabulary was not effective to achieve the students' vocabulary because it was hard for the students to memorize it. So, to solve this problem, the writer used a strategy to improve the students'[ mastery in vocabulary. The strategy was using songs. The aim of this research was to find out a significant effect of using English songs to improve students' vocabulary mastery. This research was a quantitative research by an experimental design. In this research, there were two classes as a sample, that classes were an experimental class and a control class. Variables in this research consisted of two variables. They were English songs as variable $\mathrm{X}$ and students' vocabulary mastery as variable $\mathrm{Y}$. The total number of population was 54 students, which were finally selected 40 students as sample of this study. The sample was determined based on cluster sampling of an equal chance to be taken, regardless of their typical of groups. The result of the research showed that the students' ability on vocabulary mastery test in experiment class was very good level, which was 82.25, and in control class was good level, which was 63.25. on the inferential analysis, the significant value was 0.000 higher than alpha 0.05 , which meant the alternative hypothesis (Ha) was accepted. It means that using English songs can improve the students' vocabulary mastery.
\end{abstract}

Keywords: Vocabulary, English songs, experimental research.

\section{A. Introduction}

Vocabulary is the entire words that make up a language. Before someone studies about the English skill, he should learn about vocabulary as the first step. Vocabulary is one of the important factors in all language teaching, student must continually be learning words as they learn structure and as they practice sound system.

When looking the teacher teaching at SMPN 1 Kampar Timur, the writer found that the ability of the students in memorizing vocabulary is low. This is caused by the students' prior knowledge of vocabulary is low. And also, the ability of each student in 
memorizing the vocabulary is different. Besides that, the writer found that the ability of the students in pronouncing vocabulary is bad. Because in pronouncing vocabulary, the students must know how to pronounce vocabulary because English vocabulary is not the same with Bahasa Indonesia in pronouncing vocabulary. And then, the students have difficulty to use vocabulary in sentences. It is caused by the different kinds of word classes in English vocabulary, such as noun, pronoun, verb 1 , verb 2, verb 3, helping verb, etc.

Therefore, the teachers should have several strategies to make their students motivated to learn English. The learners need a way of teaching that is enjoyable and practical so that finally they can integrate themselves into English, for example singing English songs can get the students integrated to English. It is assumed that they can contribute many things to improve student's capabilities, especially in their skill elements, such as vocabulary enrichment, listening and speaking. Singing English song is believed to have direct influence on the pronunciation skills. This paper tries to find out whether songs can improve achievement in vocabulary.

From the phenomena, the researcher tried to reduce the problems of the students' vocabulary, therefore, the writer had a study on improving students' vocabulary mastery by using English songs. However, the writer formulated a research question on how English songs improves the students' vocabulary mastery at SMPN 1 Kampar Timur.

\section{B. Review of Related Literature}

According to Hornby (1990, p.1133), song is a piece of music with words that is sung. Song is also a great language package that bundles culture, vocabulary, listening, grammar and a host of other language skills in just a few rhymes. Songs can also provide a relaxed lesson on a hot boring day.

Almost everyone loves songs. It is a part of our language and life from before birth onwards. As a baby, we often hear our mother and father sing a song to deliver us sleep in the bedroom. When young children, we play, sing, and dance to a rhyme. As adolescents, we consume the beat of popular songs artist in the world. As adults, we often hear song on television, movies, theater, and even nightly news. When we work, when we play, song is there to reinforce or every mood and emotion.

\section{Vocabulary Mastery}

According to Cameron (2001:78), vocabulary skill included: pronunciation, spelling, grammar and meaning.

1. Pronunciation

Pronunciation is one of the aspects that have a great influence of vocabulary. "Pronunciation is the way in which a particular person pronounces the word of a language" (Wehmeler, 2003:1057). Children need to hear a new word in foreign language in order they can notice the sound at the beginning and at the end, the stress pattern of the word. There is different pronunciation between English and Indonesia vocabularies, as it is stated by Sailun (2001:24): "Every language has special phonemes. English has different sound with Indonesia/ Malaysia sound. therefore, students have problems in pronunciation. the students have difficulties for some reasons. The first reason, of course, is that some sounds of English do not exist in Indonesia and Malaysia. 
The phoneme / o / (thin) and / $\theta$ / (this) are found of course, it is not appeared both English and Indonesia. Thus, in learning pronunciation, one must learn or not only to form sound correctly, but also to use them in the correctly place.

"Ur (1997:54) gives his ideas in helping students' pronunciation:

1. Imitating teacher or recorded model of sound word and sentences

2. Recording of learner speech, contrasted with native model

3. Systematic explanation and instruction (including detail of the structure and movement of part of the mouth)

4. Imitation drill, repetition of sounds, words and sentences

5. Choral repetition of drill

6. Varied repetition of drill

7. Tongue twister

8. Learning and performing dialog

9. Self-correction through listening to recording of own speech

2. Spelling

Children also need to know the letters and syllables that make up the word that is called spelling. "Spelling is the act of forming words correctly from individual letter or the way that a word is spelt" (Wehmeler, 2003:1293).

3. Grammar

Grammatical information is tied into words, and learning words can take students along the way into grammar. This suggests that if we give a high priority to vocabulary, we are not thereby abandoning grammar. (Cameron, 2001:72). Ur (1997:61) also points out that: The grammar of vocabulary need to be taught if this is not obviously covered by the grammatical rules. When teaching a new verb, for example, we might give also its past form. If this is irregular (think, thought) and we might note if transitive or intransitive is. Similarly, when teaching a noun the teacher may wish to present its plural form, if irregular (mouse, mice) or draw students' attention to the fact that it has no plural at all (advice, information). The eacher may present verb such as want and enjoy together with the verb form that follows them (want to, enjoying) or adjectives or verb together with their following prepositions.

4. Meaning

Nation and Cameron (2001:85) argue ways to explain the meaning of new words in the young learner classroom that is by using an object, a cut-out figure, gesture, performing and action, photograph, drawing or diagram on the board, and pictures from story books. Actually, finding the meaning for the new foreign language word is the amount of mental work done by the learner affects well a new word is engraved in memory, the students have to think it's about word and meaning, the more likely they are to remember it. Ur (1997:62) says that to find the meaning it can be done through translation that is word in learners' mother tongue that are equivalent in meaning to the item being taught. It can be concluded that pronunciation, spelling, grammar and meaning are the indicators of vocabulary mastery.

\section{The Use of Song as Authentic Listening Material}

The use of authentic materials is an important factor to take into consideration when designing listening skill materials. By using such listening 
materials, a learner is given the chance to develop the skills needed to comprehend and to use language that is commonly found in real situations. Therefore, it is important to take the opportunity wherever possible to expose students to example of real language usage to help them become more communicatively competent.

When designing lessons and teaching materials to further develop listening comprehension skills, students need to be motivated and stay motivated. This is best accomplished by determining the suitable of the listening materials such as the use of songs as authentic material. The use of song stimulates and motivates students to comprehend the content of materials.

In addition, the use of songs in teaching and learning English as a foreign language is felt much needed. From the songs, we can learn many things such as vocabulary, grammar, listening, speaking, writing, and especially in listening.

\section{Selection of the Songs}

When the teacher will apply songs in her/ his teaching learning process, she /he should know what kind of song she would bring into the class. This is the problem if the teacher wants to use songs to her class. There are two ways to solve the problem about the way in selecting the songs to be brought into the class: the first is to have students bring their own favorite songs to class. If they do this, however, the teacher may want to have time (a day or two) to listen to the songs and try to understand the lyrics, the second way is to use older songs, to ask students whether they still have merit, whether they like them, despite their antiquity. Teachers then can choose songs, which they like and appropriate to the topic and subject matter.
On this research, the writer chooses an older song used to improve students' vocabulary entitle "Are you sleeping". This is the lyric of the song:

\section{Are You Sleeping}

Are you sleeping?

Are you sleeping?

\section{Brother Jhon}

Brother Jhon

Morning bells are ringing

Morning bells are ringing

Ding dong ding

Ding dong ding.

This song is suitable with the topic about daily activity. furthermore, the students can add their vocabulary in their mind. So, they can try to pronounce the vocabulary in this song correctly and use the vocabulary in make sentences.

Vocabulary plays an important role because it appears in every language skills. Vocabulary building is really important in any language learning. Once a student has mastered the fundamental grammatical patterns of a language, his next task is to master its vocabulary that he needs. Nobody ever learns all the words in any language. We know and use the words that suit our particular purposes and we continue to learn new words as long as we live. It is clear enough that everybody who learns a language as a foreign language is hoped to know and master the vocabulary to improve the language skills. Vocabulary becomes a major problem in learning English, teachers of kindergarten emphasizes on this matter earlier. In teaching vocabulary, generally the teachers teach new words 
taken from reading text. It means that she integrates vocabulary with reading. This integration will lead to integrative lesson plan.

In some literature, we found the meaning of vocabulary. There are some definitions of vocabulary. Vocabulary is a component of language that maintains all of information about meaning and using word in language.

Vocabulary is a component of language and numbers of words by a person class, profession, etc. In the communication and every aspect of life such as in trade, education, business, social, politic, etc.

Nation (2001) has divided vocabulary in the specific reference, such a word.

a. Receptive Vocabulary: Knowing a word involves being able to recognize it when it is heard (What is the sound like?) or when it is seen (What does it look like?) and having an expectation of what grammatical pattern the word will occur. This includes being able to distinguish it from words with a similar form and being able to judge if the word form sounds right or look right.

b. Productive Vocabulary: Knowing a word involves being able to pronounce the word, how to write and to spell it, how to use it in grammatical pattern along with the word in usually collocate with it, it also involves not using the word too often if it is typically a low frequency word and using it in a suitable situation using the word to stand for the meaning it represents and being able to think of suitable substitutes for the word if there is any.

Teaching English Song Procedure
There are various ways of using songs in the classroom. The level of the students, the interests and the age of the learners, the grammar point to be studied, and the song itself have determinant roles on the procedure. Apart from them, it mainly depends on the creativity of the teacher.

At the primary level of singing the song, the prosodic features of the language are emphasized. At the higher levels, where the practice of grammar points is at the foreground, songs can be used with several techniques. Some examples of these techniques are:
a. Gap fills or closes texts
b. Focus questions
c. True-false statements
d. Put these lines into the correct sequence
e. Dictation
f. Add a final verse
g. Circle the antonyms/synonyms of the given words
h. Discuss

On the other hand, procedure of songs activity can be done by steps below:

a. Pre-listening

1) As a warm-up or schema building activity, ask students what they know about American pop culture. You might also want to bring some pictures or CD's of popular actors or singers to class.

2) Pass out the cloze activity handout, and have students read the lyrics and figure out what the missing words might be by using their knowledge of grammar. Have the students compare their guesses with their neighbors. Then, ask for volunteers to share their guesses with the class.

b. While-listening 
Students listen for the missing words. Play the song once, and ask students whether they need to listen to the song again. If they do, play it one more time.

c. Post-listening

After the second listening, go over the answers with the class. If necessary, replay the parts where students had trouble understanding the words. Go over grammar points as necessary.

However, in teaching listening by songs, there are three stages; prelistening, while-listening, and postlistening. Beside of that, the activity can be formed gap fills or close texts, true-false statements, and dictation.

By using songs in the classroom, students can practice their listening skills and increase their cultural knowledge. Almost any song can be used in the ESL classroom. The pronunciation and rhythm lessons are the same as for the children's songs and the lessons may help students become more interested in different types of songs. Practicing lyric reading, studying the vocabulary, and listening to various songs can help students become more familiar with popular songs and make them more confident in their ability to listen and understand the world around them (Brown, 2006).

The other benefits of using songs in the classroom are songs can be used:

a. to present a topic, a language point, lexis, etc.

b. to practice a language point, lexis, etc.

c. to focus on common learner errors in a more direct way.

d. to encourage extensive and intensive listening.

e. to stimulate discussion of attitudes and feelings.

f. to encourage creativity and use of imagination.

g. to provide a relaxed classroom atmosphere.

h. to bring variety and fun to learning.

From explanation above, it's considered that songs have many benefits. Some of them are songs can motivate the students and make them more confidence in their ability to listen the materials.

Based on the phenomena found by the writer, the alternative way to improve students' vocabulary mastery is by using songs. The operational concept can be drawn in theoretical framework table as follow:

Table 1. The Theoretical Framework of the Research

\section{Improving students' vocabulary mastery by using songs}

\section{Theory}

\begin{tabular}{lll}
\hline \multicolumn{1}{c}{ Element } & \multicolumn{1}{c}{ Indicators } & \\
\hline $\begin{array}{l}\text { Memorizing } \\
\text { vocabulary }\end{array}$ & $\begin{array}{l}\text { The students are able to } \\
\text { memorize vocabulary } \\
\text { of daily activities. }\end{array}$ & $\begin{array}{l}\text { (British Council English Online Teacher: A } \\
\text { Lesson, n.d.) }\end{array}$ \\
\hline $\begin{array}{l}\text { Pronouncing } \\
\text { vocabulary }\end{array}$ & $\begin{array}{l}\text { The students are able to } \\
\text { pronounce vocabulary }\end{array}$ & $\begin{array}{l}\text { (Full text of "Pronouncing vocabulary of } \\
\text { geographical and personal names, 2011) }\end{array}$
\end{tabular}




\section{of daily activities.}

Using The students are able to (British Council English Online Teacher: A vocabulary use vocabulary of daily Framework for Planning a Listening Skills in sentences activities in sentences. Lesson, n.d.)

\section{Research Design}

The design of the study is an experimental research, intended to find out of using song in teaching vocabulary. In this research, the writer uses two classes as sample that one of them is called experimental class administered by using song and another one named control class that is administered without using song. However, the materials given and purpose of the research to each class are the same. There are two kinds of tests given in this research, they are pre-test given before the treatment that aims at finding out the homogeneity of the two classes and post-test after the treatment is to find out whether or not using song can improve the students' vocabulary mastery. The following schema shows the research design:

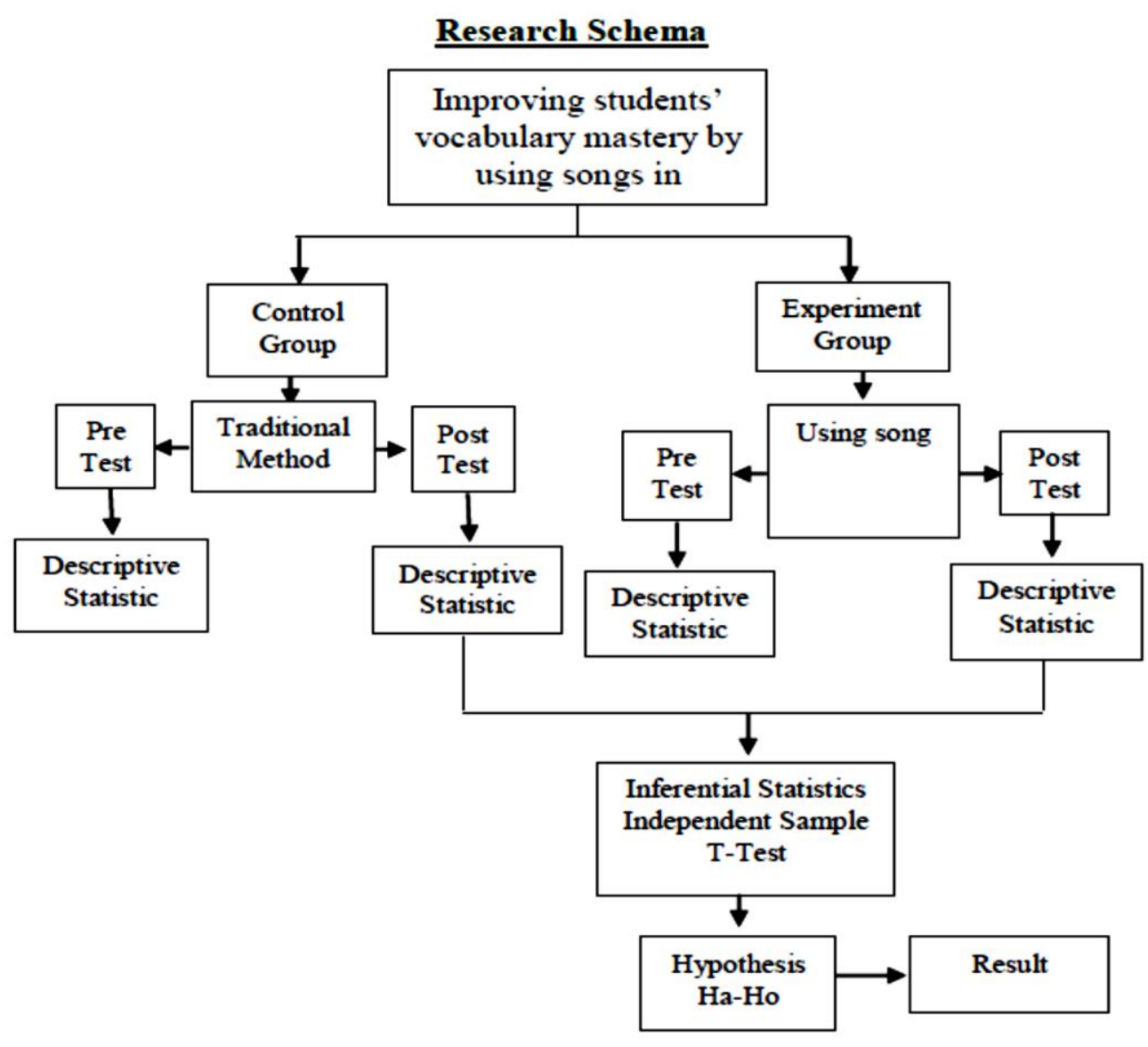

This research conducted at the eighth-grade students of SMPN 1 Kampar Timur, Kampar regency, Riau Province. The population of this research is the eighth-year students of SMPN 1 Kampar Timur, Kampar regency, Riau Province, which are chosen from two classes. The total 
numbers of students are 54. Before taking the sample of the students, the writer gave the multiple-choice test to them, and then the writer divided groups according to the categories. Furthermore, the writer took the sample from middle to low categories and divided it into two classes, named by experimental and control classes by using technique of randomization (Cohen, 2001). After the writer gave the test, so the sample of this research can be seen as follow:

Table 2. The Sample of the Research

\begin{tabular}{ccc}
\hline \multicolumn{2}{c}{ Sample } & Total \\
\cline { 1 - 2 } Experiment & Control & \\
\hline 20 & 20 & 40 \\
\hline
\end{tabular}

Try out is a test to be conducted to all population. The try out measures the reliability and validity of the test items. The test in try out was 20 items. The duration of try out was 30 minutes.

Moreover, it is used to know the students' ability on vocabulary mastery. There were Pre- test and Post -test in teaching vocabulary. Pre- test is held to find out achievement at the starting or before teaching. Post- test is aimed to see the increasing or different achievement after being taught. The test for this research used multiple choices, which consisted of 20 items for identifying vocabulary. The duration of test was 30 minutes.

Based on the formulation of the problems, objectives and the explanation theory in theoretical framework and operational concept, the writer states two assumption as follows:

Ha: There is significant increasing students' ability on vocabulary mastery by using song.
Ho: There is no significant increasing students' ability on vocabulary mastery by using song.

\section{The Research Findings}

This was an experimental research on using songs to improve students' vocabulary mastery in listening class at the eighth - year students of SMPN 1 Kampar Timur, Kampar regency, Riau Province. The data was taken twice, pre-test before carrying out using songs to improve students' vocabulary mastery in listening class and post-test after carrying out using songs to improve students' vocabulary mastery in listening class. There were two variables which were evaluated to see the significant influences on using songs to improve students' vocabulary mastery in listening class at SMPN 1 Kampar Timur, Kampar regency, Riau Province. There was an independent variable, which was symbolized by $\mathrm{Y}$ and a dependent variable, which was symbolized by $\mathrm{X}$.

Table 3. The Result of Pre-Test of the Students' Ability in Vocabulary Mastery

\begin{tabular}{cccccc}
\hline \multirow{2}{*}{ No. } & \multirow{2}{*}{ Students } & \multicolumn{2}{c}{ Experiment } & \multicolumn{2}{c}{ Control } \\
\cline { 3 - 6 } & & Score & Category & Score & Category \\
\hline 1 & Student 1 & $\mathbf{6 5}$ & Good & $\mathbf{4 5}$ & Bad \\
2 & Student 2 & $\mathbf{5 0}$ & Bad & $\mathbf{4 0}$ & Bad \\
3 & Student 3 & $\mathbf{6 5}$ & Good & $\mathbf{5 5}$ & Bad
\end{tabular}




\begin{tabular}{clllll}
4 & Student 4 & $\mathbf{6 5}$ & Good & $\mathbf{4 0}$ & Bad \\
5 & Student 5 & $\mathbf{4 5}$ & Bad & $\mathbf{4 5}$ & Bad \\
6 & Student 6 & $\mathbf{5 0}$ & Bad & $\mathbf{4 0}$ & Bad \\
7 & Student 7 & $\mathbf{4 0}$ & Bad & $\mathbf{4 0}$ & Bad \\
8 & Student 8 & $\mathbf{4 5}$ & Bad & $\mathbf{5 5}$ & Bad \\
9 & Student 9 & $\mathbf{4 0}$ & Bad & $\mathbf{5 5}$ & Bad \\
10 & Student 10 & $\mathbf{5 5}$ & Bad & $\mathbf{5 5}$ & Bad \\
11 & Student 11 & $\mathbf{4 0}$ & Bad & $\mathbf{5 0}$ & Bad \\
12 & Student 12 & $\mathbf{4 5}$ & Bad & $\mathbf{6 0}$ & Good \\
13 & Student 13 & $\mathbf{4 0}$ & Bad & $\mathbf{5 0}$ & Bad \\
14 & Student 14 & $\mathbf{4 0}$ & Bad & $\mathbf{6 5}$ & Good \\
15 & Student 15 & $\mathbf{5 5}$ & Bad & $\mathbf{4 5}$ & Bad \\
16 & Student 16 & $\mathbf{5 5}$ & Bad & $\mathbf{5 0}$ & Bad \\
17 & Student 17 & $\mathbf{5 5}$ & Bad & $\mathbf{4 0}$ & Bad \\
18 & Student 18 & $\mathbf{5 0}$ & Bad & $\mathbf{4 5}$ & Bad \\
19 & Student 19 & $\mathbf{2 5}$ & Bad & $\mathbf{4 0}$ & Bad \\
20 & Student 20 & $\mathbf{5 0}$ & Bad & $\mathbf{5 5}$ & Bad \\
\hline
\end{tabular}

Table 4. The Result of Post-Test of the Students' Ability in Vocabulary Mastery

\begin{tabular}{cccccc}
\hline & & \multicolumn{2}{c}{ Experiment } & \multicolumn{2}{c}{ Control } \\
\cline { 3 - 6 } No. & Students & Score & Category & Score & Category \\
\hline 1 & Student 1 & $\mathbf{9 0}$ & Excellent & $\mathbf{8 0}$ & Very good \\
2 & Student 2 & $\mathbf{8 5}$ & Very good & $\mathbf{6 5}$ & Good \\
3 & Student 3 & $\mathbf{8 5}$ & Very good & $\mathbf{7 5}$ & Good \\
4 & Student 4 & $\mathbf{8 0}$ & Very good & $\mathbf{8 0}$ & Very good \\
5 & Student 5 & $\mathbf{8 5}$ & Very good & $\mathbf{6 0}$ & Good \\
6 & Student 6 & $\mathbf{8 5}$ & Very good & $\mathbf{6 5}$ & Good \\
7 & Student 7 & $\mathbf{9 0}$ & Excellent & $\mathbf{6 0}$ & Good \\
8 & Student 8 & $\mathbf{9 5}$ & Excellent & $\mathbf{7 0}$ & Good \\
9 & Student 9 & $\mathbf{8 0}$ & Very good & $\mathbf{5 5}$ & Bad \\
10 & Student 10 & $\mathbf{8 5}$ & Very good & $\mathbf{6 0}$ & Good \\
11 & Student 11 & $\mathbf{9 5}$ & Excellent & $\mathbf{4 5}$ & Bad \\
12 & Student 12 & $\mathbf{8 0}$ & Very good & $\mathbf{6 5}$ & Good \\
13 & Student 13 & $\mathbf{7 5}$ & Good & $\mathbf{6 0}$ & Good \\
14 & Student 14 & $\mathbf{6 5}$ & Good & $\mathbf{7 0}$ & Good \\
15 & Student 15 & $\mathbf{5 5}$ & Bad & $\mathbf{6 0}$ & Good \\
16 & Student 16 & $\mathbf{8 0}$ & Very good & $\mathbf{6 5}$ & Good \\
17 & Student 17 & $\mathbf{8 0}$ & Very good & $\mathbf{6 0}$ & Good \\
18 & Student 18 & $\mathbf{8 5}$ & Very good & $\mathbf{7 0}$ & Good \\
19 & Student 19 & $\mathbf{8 5}$ & Very good & $\mathbf{4 5}$ & Bad \\
20 & Student 20 & $\mathbf{8 5}$ & Very good & $\mathbf{5 5}$ & Bad \\
\hline
\end{tabular}

From the table above, we can know the total score of pre-test for experimental group was 975 , while the highest score was 65 and the lowest score was 40. The total score of pre-test for control group was 970, while the 
highest score was 65 and the lowest score was 40. And the total score of post-test for experimental group was 1645, while the highest score was 95 and the lowest score was 55. The total score of post-test for control group was 1265, while the highest score was 80 and the lowest score was 45 .

\section{a. Descriptive Analysis}

Table 5. The Result of Pre-Test on Experiment and Control Group

Statistics

\begin{tabular}{lccc}
\hline \multirow{2}{*}{$\mathbf{N}$} & Experiment_Class & Control_Class \\
\cline { 2 - 4 } & Valid & $\mathbf{2 0}$ & $\mathbf{2 0}$ \\
\cline { 2 - 4 } & Missing & $\mathbf{0}$ & $\mathbf{0}$ \\
\hline Mean & 48.75 & 48.50 \\
Median & 50.00 & 47.50 \\
Mode & 40 & 40 \\
Std. Deviation & 10.114 & 7.626 \\
Variance & 102.303 & 58.158 \\
Range & 40 & 25 \\
Minimum & 25 & 40 \\
Maximum & 65 & 65 \\
Sum & 975 & 970 \\
\hline
\end{tabular}

From the table Pre-Test above on the experimental and control classes found that: in Experiment class, Mean was 48.75 Median was 50, Mode was 40, Standard Deviation was 10.114 , Variance was 102.303, Range was 40, Minimum was 25, Maximum was 65 and Sum was 975. On the other hand, in Control class, Mean was 48.50, Median was 47.5, Mode was 40, Standard Deviation was 7.626, Variance was 58.158, Range was 25, Minimum was 40, Maximum was 65 and Sum was 970.

Table 6. The Result of Post-Test on Experiment and Control Group

Statistics

\begin{tabular}{lccc}
\hline & & Experiment_Class & Control_Class \\
\cline { 2 - 4 } $\mathbf{N}$ & Valid & $\mathbf{2 0}$ & $\mathbf{2 0}$ \\
\cline { 2 - 4 } & Missing & $\mathbf{0}$ & $\mathbf{0}$ \\
\hline Mean & 82.25 & 63.25 \\
Median & 85 & 62.5 \\
Mode & 85 & 80 \\
Std. Deviation & 9.244 & 9.497 \\
Variance & 85.481 & 90.197 \\
Range & 40 & 35 \\
Minimum & 55 & 45 \\
Maximum & 95 & 80 \\
Sum & 1645 & 1265 \\
\hline
\end{tabular}


From the table of the Post-Test above on the experimental and control classes, it was found that: in Experiment class, Mean was 82.25, Median was 85 , Mode was 85 , Standard Deviation was 9.244 , Variance was 85.481, Range was 40 , Minimum was 55 , Maximum was 95 and Sum was 1645 . While, in Control class, Mean was 63.25, Median was 62.5, Mode was 80, Standard Deviation was 9.497, Variance was 90.197, Range was 35, Minimum was 45, Maximum was 80 and Sum was 1265.

\section{b. Inferential Analysis}

Table 7. Independent Samples Test

\begin{tabular}{|c|c|c|c|c|c|c|c|c|c|c|}
\hline \multicolumn{4}{|c|}{$\begin{array}{c}\text { Levene's Test for Equality of } \\
\text { Variances }\end{array}$} & \multicolumn{7}{|c|}{ T-test for Equality of Means } \\
\hline & & & & & & & & & \multicolumn{2}{|c|}{$\begin{array}{l}95 \% \text { Confidence } \\
\text { Interval of the } \\
\text { Difference }\end{array}$} \\
\hline & & $\mathbf{F}$ & Sig. & $\mathbf{t}$ & df & $\begin{array}{l}\text { Sig. (2- } \\
\text { tailed) }\end{array}$ & $\begin{array}{c}\text { Mean } \\
\text { Differe } \\
\text { nce }\end{array}$ & $\begin{array}{c}\text { Std. } \\
\text { Error } \\
\text { Differ } \\
\text { ence }\end{array}$ & Lower & Upper \\
\hline \multirow[b]{2}{*}{$\begin{array}{l}\text { Vocabular } \\
\text { y mastery }\end{array}$} & $\begin{array}{l}\text { Equal } \\
\text { variances } \\
\text { assumed }\end{array}$ & .230 & .634 & 6.411 & 38 & .000 & 19.000 & 2.964 & 13.001 & 24.999 \\
\hline & $\begin{array}{l}\text { Equal } \\
\text { variances } \\
\text { not } \\
\text { assumed }\end{array}$ & & & 6.411 & $\begin{array}{c}37.9 \\
72\end{array}$ & .000 & 19.000 & 2.964 & 13.000 & 25.000 \\
\hline
\end{tabular}

From the above table, the significant value was 0.000 higher than alpha 0.05 , which meant the alternative hypothesis (Ha) was accepted. Therefore, using songs significantly affected toward the students' vocabulary mastery.

\section{E. Conclusion and Suggestion}

After having the test, the result of the student's ability on vocabulary mastery test in experiment class was very good level, which was 82.25 , and in control class was good level, which was 63.25. on the inferential analysis, the significant value was 0.000 higher than alpha 0.05, which meant the alternative hypothesis (Ha) was accepted. Therefore, using songs can improve the students' vocabulary mastery.

Based on the result of the data analysis, it can be concluded that there is a significant effect of using songs toward students' ability on vocabulary mastery at SMPN 1 Kampar Timur, Kampar regency, Riau Province.

The writer would like to suggest that using songs can increase students' vocabulary mastery and give motivation to the students in learning English. Furthermore, this research finding will give any varieties of teaching methodology in order to overcome the students' difficulties in enhancing their English vocabulary. 


\section{Reference}

Hornby, AS. 1987. Oxford Advanced Learner's Dictionary of Current English. Oxford University Press. New York.

Aban, Caria. 1996. Learning through Songs and Music. Language Travel. http://www.languagetravels. com/music.html.

Arikunto, Suharsimi, at all. 2006. Makes the Case for Using Music in the Classroom. Retrieved from website:http://www.songs forteaching.com/references.htm on May, 6th, 2009.

Brown, H. Douglas. 2002. Language Assessment. Principles and Classroom Practices. San Francisco State University. Longman.

Cameron, Lynne. 2001. Teaching Language to Young Learner. Cambridge Language Teaching Library. Cambridge: Cambridge University Press.

Gay L. R. and Peter Airasian. 2000. Educational Research: Competencies for Analysis and Application. (6th Ed). Saddle River, New Jersey. Prentice Hall.

Graves. 2000. The Roles of Instruction in Fostering Vocabulary Development. The Nature of Vocabulary Acquisition. New York: Laurence Erlbaum.

Jhonson, Andrew. 2005. A Short Guide to Action Research. Boston: Pearson Education, Inc.

Kavaliauskiene, Galina. 2009. Music in the ESP Classroom. Retrieved from the website: http://www. teachingenglish. org.uk/talk/questions/using-songs on September 7th, 2009.

Larry, M. Lynch. 2009. Reason Why We Should Used Songs to Teach Vocabulary. Retrieved on September 3, 2007 at e-mail. mail to: lynchlarrym@gmail.com. Improving Students' Vocabulary Mastery by Using Songs at The Grade Sixth of State Elementary School of 45 Bungo Pasang Padang EDU RESEARCH; Jurnal Pendidikan Vol.1 No.1 Juli 2

Nation. 1990. Teaching and Learning Vocabulary. Wellington: New Burry House Publishers.

O’Malley, J.Michael \& Piere, L. Valdez.1996. Authentic Assement for English Language Learner. Pratical Approach for Teacher. New York: Addison Wesley Publishing Company.

Orlova, Notalia. 1997. Developing Speech Habits With the Help of Song. English Teaching Forum. Vol XXVI: 13-18.

Rodgers, Paul. 2002. Using Songs to Teach Pronunciation and Grammar. Retrieved September 21, 2008 from englishtoday2002@yahoo.com

Saricoban, Arif dan Esen Metin. 2000. Songs, Verse and Games for Teaching Grammar. The Internet TESL Journal, Vol. VI, No. 10, http://iteslj.org/. Course in Language Teaching: Practice and Theory. Cambridge: Cambridge University Press.

Ur, Penny. 1997. A Course in Language Teaching: Practice and Theory. Cambridge: Cambridge University Pres 